\title{
HUBUNGAN ASAL JURUSAN, STATUS EKONOMI ORANGTUA, DUKUNGAN SOSIAL KELUARGA DENGAN MOTIVASI BELAJAR PADA MAHASISWA SEMESTER IV
}

(Studi S1 Ilmu Keperawatan Sekolah Tinggi Ilmu Kesehatan Yayasan Rumah Sakit Islam Surabaya).

\section{Umdatus Soleha}

\begin{abstract}
Background: SomeHealth Science High Schoolshave students fromnon-science majors. Hypothesized,studentswould bemore motivatedtolearnif theyhave astrong foundationandrelevanceof sciencerelevant to themajorswhilein a high school. This studyaimed toanalyze the relationship of major origin withthe learning motivation by controlling the influence of parents' economic statusandfamily social support.
\end{abstract}

Subjects and Methods: This studywasan observationalanalyticstudywithcross sectional approach. The sample of 45 college students was selectedbystratified randomsamplingofthe student populationat S1 Nursing ScienceDepartment of Health SciencesIslamicFoundation HospitalSurabaya. Data collection was conductedfromMarch 10tillMarch 17, 2013. Independent variables studied includedmajororigin, economic status of parents, familysocialsupport, while thedependent variableis a learning motivation. Learning motivationandfamilysocialsupportwere measuredwith a questionnairethathadbeen tested. Datawere analyzed bymultiple logisticregression analysis model.

Result \& Conclusion: The result of the study concludes that there are relationshipmajororigin $(\mathrm{OR}=1.90, \mathrm{p}=0.335)$, parentalsocioeconomic status $(\mathrm{OR}=0.72, \mathrm{p}=0611)$ andfamilysocial support $(\mathrm{OR}=1.47, \mathrm{p}=0.536)$ with learning motivation although they are not statistically significant. The writer suggests that it still needs further studywitha larger samplesize.

Abstrak: Beberapa Stikes memiliki input mahasiswa yang berasal dari jurusan Non IPA. Dihipotesiskan mahasiswa akan lebih termotivasi untuk belajar jika memiliki dasar yang kuat dan relevansi keilmuan yang relevan dengan jurusan ketika di sekolah menengah. Penelitian ini bertujuan untuk menganalisis hubungan asal jurusan dengan motivasi belajar dengan mengontrol pengaruh status ekonomi orangtua dan dukungan sosial keluarga.

Penelitian ini adalah penelitian analitik observasional dengan pendekatan crossectional. besar Sampel sebanyak 45 mahasiswa di pilih dengan teknik stratified random sampling dari populasi mahasiswa pada Prodi S1 Ilmu Keperawatan Stikes Yarsis. Pengumpulan data dilakukan dari tanggal 10 Maret s.d 17 Maret 2013. Variabel independen yang diteliti meliputi asal jurusan, status ekonomi orangtua, dukungan sosial keluarga, sedangkan variabel dependen adalah motivasi belajar. Motivasi belajar dan dukungan social keluarga di ukur dengan kuesioner yang telah dilakukan uji coba. Data di analisis dengan model analisis regresi logistik ganda.

Hasil penelitian menyimpulkan terdapat hubungan asal jurusan $(\mathrm{OR}=1.90, \mathrm{p}=0.335)$, status ekonomi orangtua $(\mathrm{OR}=0.72, \mathrm{p}=0.611)$ dan dukungan sosial keluarga $(\mathrm{OR}=1.47, \mathrm{p}=0.536)$ dengan motivasi belajar meskipun secara statistik tidak signifikan. Perlu penelitian lebih lanjut dengan ukuran sampel yang lebih besar. 
Key words: The Major Origin, Economic Status, Social Support, Learning Motivation.

\section{PENDAHULUAN}

Di dalam perguruan tinggi mahasiswa dituntut untuk belajar dan berprestasi dengan baik. Dalam meraih prestasi akademik maupun non akademik dibutuhkan motivasi belajar yang tinggi dalam dirinya. Mahasiswa yang termotivasi untuk belajar sesuatu, akan berusaha mempelajarinya dengan baik dan tekun, dengan harapan akan mendapatkan hasil yang baik (Uno, 2011).

Motivasi belajar pada mahasiswa dapat berasal dari dalam diri atau motivasi instrinsik dan dari luar diri atau motivasi ekstrinsik (Djamarah, 2011).

Siswa atau pelajar memiliki kebutuhankebutuhan yang dapat membantu kegiatan proses belajar mengajar, diantaranya kebutuhan jasmaniah misalnya kebutuhan makan, minum, kesehatan serta sarana penunjang pembelajaran (Sardiman, 2011). Anak yang berasal dari keluarga mampu, dapat memenuhi segala keperluan yang berhubungan dengan dunia pendidikan, tentunya akan berbeda dengan anak yang berasal dari keluarga biasa-biasa saja (Subini, 2012).

Selain kebutuhan jasmaniah, kebutuhan intelektual dan kebutuhan sosial sangat membantu suksesnya proses belajar mengajar (Sardiman, 2011). Kebutuhan intelektual berkaitan erat dengan kemampuan mahasiswa atau pelajar dalam mempelajari sesuatu, seorang siswa yang berminat belajar Ilmu Pengetahuan Alam tidak dapat dipaksakan untuk belajar ilmuilmu sosial, sehingga guru diharapkan dapat menciptakan suasana belajar yang dapat menyalurkan kemampuan mereka.

Sekolah Tinggi Ilmu Kesehatan Yayasan Rumah Sakit Islam Surabaya (Stikes Yarsis) adalah institusi pendidikan yang menghasilkan tenaga kesehatan khususnya perawat dan bidan. Stikes Yarsis memiliki
Program Studi Diploma III Keperawatan, Diploma III Kebidanan, S1 Ilmu Keperawatan serta Program Studi Pendidikan Profesi Ners.

Dalam rangka menghasilkan lulusan yang baik, berbagai upaya dilakukan Stikes Yarsis mulai dari mencari input yang baik, melaksanakan proses pembelajaran yang baik, pemenuhan sarana dan prasarana pembelajaran yang baik, serta upaya mendapatkan umpan balik dari pengguna lulusan (user) sebagai masukan dalam memperbaiki proses pembelajaran bahkan untuk kebutuhan redesign kurikulum. Apapun upaya yang telah dilakukan oleh Stikes Yarsis, prestasi belajar yang baik juga ditentukan oleh karakteristik mahasiswa atau peserta didik.

Data dari bidang Akademik \& Kemahasiswaan Stikes Yarsis tahun 2012 menunjukkan ada 7 mahasiswa angkatan tahun 2008, 3 mahasiswa angkatan tahun 2009, 2 mahasiswa angkatan tahun 2010 dan 1 mahasiswa angkatan tahun 2011 keluar karena mahasiswa kurang memiliki motivasi baik dalam mengikuti Proses Belajar Mengajar (PBM), salah satunya dapat dilihat dari rekapitulasi kehadiran mahasiswa dalam mengikuti perkuliahan, beberapa mahasiswa, orangtuanya tidak mengetahui kalau mereka jarang mengikuti perkuliahan, padahal informasi dari orangtua mengenai pembiayaan pendidikan selalu terpenuhi dan mereka selalu menginformasikan kalau rajin kuliah.

Fenomena yang ada menunjukkan seakan-akan orangtua yang termotivasi tinggi mendukung proses belajar mengajar anaknya namun tidak diimbangi oleh keseriusan anak dalam mengikuti PBM. Hal demikianlah yang nantinya akan 
menyebabkan prestasi anak menjadi tidak baik bahkan belajar tidak sampai tuntas.

Beberapa mahasiswa yang bermasalah dengan perkuliahan, ada yang menyampaikan bahwasanya mereka kurang menyukai program studi yang sedang diikuti sekarang ini, dan beberapa mahasiswa yang berasal dari background orangtua yang bekerja sebagai Tenaga Kerja Indonesia, dimana mereka tinggalnya sangat berjauhan dan mahasiswa mengatakan kurang mendapatkan perhatian atau dukungan orangtua sehingga mereka mencari teman dekat yang menurut mereka dapat meringankan beban psikologis atau masalah yang sedang dihadapi (Bidang Administrasi Kemahasiswaan Stikes Yarsis, 2010).

Mereka masuk ke Program Studi Keperawatan karena paksaan dan keinginan dari orangtua, yang kelak mengidamkan anaknya untuk menjadi perawat. Dari beberapa kronologis permasalahan mahasiswa berkaitan dengan ketidakseriusannya mengikuti PBM, ada yang mengungkapkan mereka lebih senang dengan ilmu-ilmu sosial dan budaya misalnya ekonomi, geografi, seni dan lainlain.

\section{Metode Penelitian \\ Tempat dan Waktu}

Penelitian ini dilakukan di Sekolah Tinggi Ilmu Kesehatan Yayasan Rumah Sakit Islam Surabaya pada Program Studi S1 Ilmu Keperawatan. Waktu Penelitian dilaksanakan pada bulan Maret tahun 2013.

\section{Jenis Penelitian}

Jenis penelitian kuantitatif observasional, Sedangkan berdasarkan waktu, menggunakan pendekatan crossectional.

\section{Populasi dan Sampel}

Populasi sasaran adalah semua mahasiswa keperawatan. Populasi sumber adalah semua mahasiswa semester IV pada program studi S1 Ilmu Keperawatan Stikes Yarsis. Besarnya populasi adalah 134.

Besar sampel 45 orang. Sampel diambil dengan menggunakan teknik stratified random sampling dengan kelas $\mathrm{A}, \mathrm{B}$ dan $\mathrm{C}$ sebagai stratanya. Pada masing-masing kelas dilakukan random sampling.

\section{Variabel Penelitian}

Variabel Independen: Asal jurusan, Status ekonomi orang tua, dukungan sosial keluarga. Variabel dependen: Motivasi belajar

\section{Definisi Operasional Variabel}

1. Asal jurusan: Karakteristik yang dimiliki setiap mahasiswa berdasarkan jurusan yang telah dilalui atau diambil ketika di sekolah tingkat menengah atau kejuruan.

Alat ukur: kuesioner.

Skala Pengukuran: kategorikal, yaitu:

IPA dan non IPA

2. Status ekonomi orang tua; Rata-rata pendapatan orangtua (ayah dan ibu) yang diperoleh perbulan pada enam bulan terakhir. Alat ukur: kuesioner.

Skala Pengukuran: kontinu. Untuk dianalisis data diubah menjadi: kategorikal, yaitu:
a. Di atas rata-rata (tinggi) $=1$
b. Di bawah rata-rata (rendah) $=0$

3. Dukungan sosial keluarga: Kepedulian atau perhatian keluarga baik berupa informasi, fasilitas maupun saran yang dapat memberikan bantuan \& ketenangan psikologis. Alat ukur: kuesioner. Skala Pengukuran: kontinu. Untuk dianalisis data diubah menjadi: kategorikal, yaitu:
a. Di atas rata-rata (tinggi) $=1$
b. Di bawah rata-rata $($ rendah $)=0$

4. Motivasi belajar adalah upaya atau dorongan yang mempengaruhi kecenderungan perubahan perilaku untuk mencapai prestasi akademik. Alat ukur: kuesioner. Skala 
Pengukuran: kontinu. Untuk dianalisis data diubah menjadi: dikotomi, yaitu:

a. Motivasi tinggi (kode 1)

b. Motivasi rendah (kode 0 )

\section{Teknik Pengumpulan Data}

Data yang digunakan data primer, diperoleh menggunakan kuesioner.

\section{Uji Validitas dan Reliabilitas}

Uji Validitas

a. Validitas isi

Validitas isi kuesioner dinilai dengan cara memeriksa apakah item-item pertanyaan memang sudah sesuai dengan isi (content) tiap variabel.

b. Validitas muka

Kuesioner yang digunakan memperhatikan tata-bahasa, susunan itemitem pertanyaan.

c. Validitas kriteria

Menurut Murti (2010) karena instrumen ini belum bersifat baku, maka dilakukan uji validitas dan reliabilitas di populasi sumber dan berada di dalam sampel sebanyak 11 mahasiswa.

\section{Uji Reliabilitas}

Pengukuran variabel yang konsisten harus menunjukkan 2 aspek reliabilitas: (1) Konsistensi internal; dan (2) Stabilitas. Konsistensi internal yang akan diukur secara kuantitatif dalam penelitian ini dari masing-masing variabel komposit meliputi:

(1) Item-Total Correlation; (2) Split-Half Reliability.

a. Konsistensi Internal

1) Korelasi Item-Total
Item yang digunakan dalam alat ukur jika memiliki korelasi item-total $\geq$ 0.20 .

(2) Split-Half Reliability.

Variabel dukungan sosial keluarga memiliki nilai Alpha Cronbach $=0.71$ sedangkan variabel motivasi belajar memiliki nilai Alpha Cronbach $=0.84$.

\section{Teknik Analisis Data}

Karakteristik sampel data kontinu dideskripsikan dalam $\mathrm{n}$, mean dan SD. Karakteristik sampel data kategorikal dideskripsikan dalam $\mathrm{n}$ dan persen.

Hubungan bivariate dianalisis dengan uji statistik chi-square. Kekuatan hubungan ditunjukkan oleh OR.

Hubungan antara asal jurusan, status ekonomi orang tua, dukungan sosial keluarga dengan motivasi belajar dianalisis dengan analisis regresi logistik ganda.

\section{HASIL PENELITIAN DAN PEMBAHASAN}

1. Hubungan Asal Jurusan dengan Motivasi Belajar

Tabel 4.9 disimpulkan mahasiswa dengan asal jurusan IPA memiliki kemungkinan 1.7 kali memiliki motivasi lebih tinggi dibanding dengan mahasiswa yang berasal dari jurusan Non IPA, akan tetapi secara statistik tidak signifikan.

2. Hubungan Status Ekonomi Orangtua dengan Motivasi Belajar.

Berdasarkan hasil penelitian yang dilakukan, tentang hubungan status ekonomi orangtua dengan motivasi belajar ditampilkan pada tabel 4.10. 


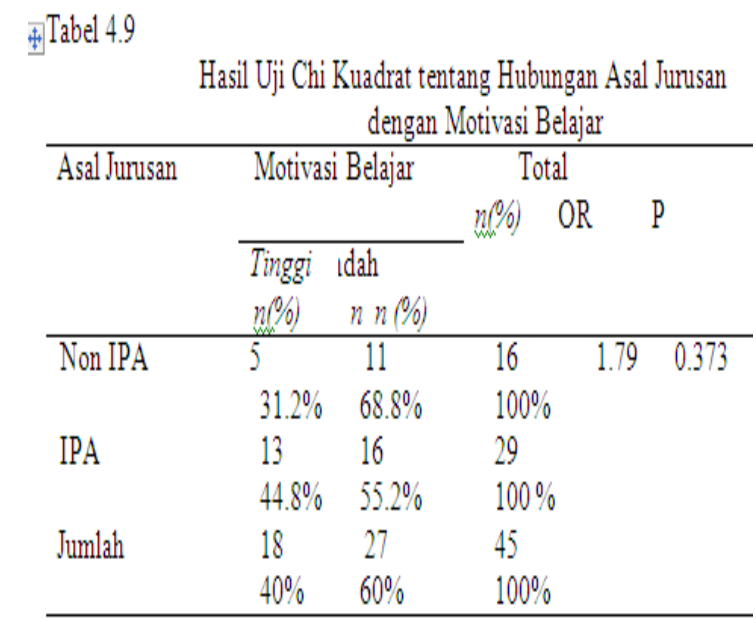

Sumber: Data Primer

GTabel 4.10

Hasil Uji Chi Kuadrat tentang Hubungan Status Ekonomi Orangtua dengan Motivasi Belajar

\begin{tabular}{|c|c|c|c|c|}
\hline \multirow{2}{*}{$\begin{array}{l}\text { Status Ekonomi } \\
\text { Orangtua }\end{array}$} & \multicolumn{2}{|c|}{ Motivasi Belajar } & \multirow{2}{*}{$\begin{array}{l}\text { otal } \\
-n(0 \%)\end{array}$} & \multirow{2}{*}{$O R \quad P$} \\
\hline & $\begin{array}{l}\text { Tinggi } \\
n(\%)\end{array}$ & $\begin{array}{l}\text { Rendah } \\
(\%)\end{array}$ & & \\
\hline <Rp.2.951.111 & $\begin{array}{c}11 \\
42.3 \%\end{array}$ & $\begin{array}{c}15 \\
57.7 \%\end{array}$ & $\begin{array}{l}26 \\
100 \%\end{array}$ & $\begin{array}{ll}0.80 & 0.712\end{array}$ \\
\hline खRp. 2.951.111 & $736.8 \%$ & $\begin{array}{l}12 \\
63.2 \%\end{array}$ & $\begin{array}{l}19 \\
100 \%\end{array}$ & \\
\hline Jumlah & $\begin{array}{l}18 \\
40 \%\end{array}$ & $\begin{array}{r}27 \\
60 \%\end{array}$ & $\begin{array}{l}45 \\
100 \%\end{array}$ & \\
\hline
\end{tabular}

Sumber: Data Primer

Tabel 4.10 disimpulkan mahasiswa yang memiliki pendapatan orangtua di atas rata-rata memiliki kemungkinan bermotivasi tinggi $8 / 10$ kali lebih rendah daripada mahasiswa yang berasal dari status ekonomi orangtua <Rp.2.951.111, akan tetapi secara statistik tidak signifikan.

\section{Analisis Hubungan Dukungan Sosial Keluarga dengan Motivasi Belajar \\ Berdasarkan hasil penelitian yang dilakukan, tentang hubungan dukungan sosial keluarga dengan motivasi belajar ditampilkan pada tabel 4.11.}




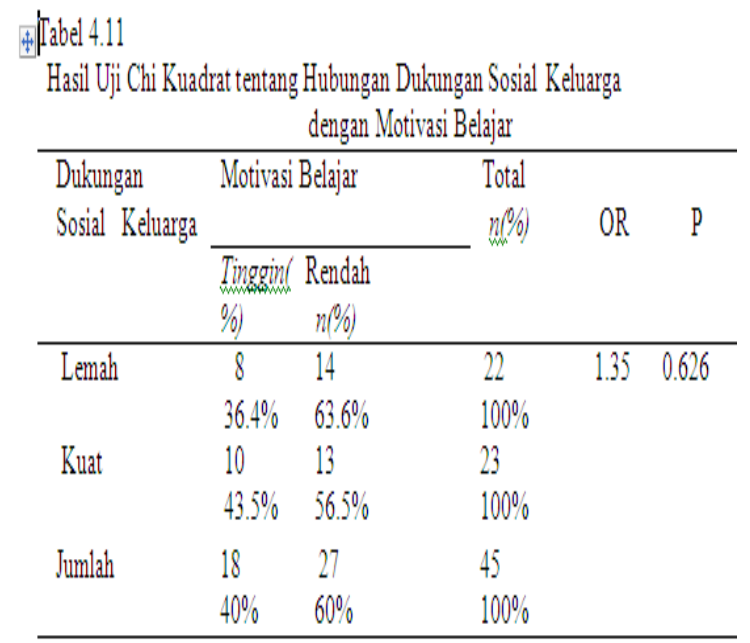

Sumber: Data Primer

Pada tabel 4.11, hasil analisis lebih lanjut disimpulkan mahasiswa yang memiliki dukungan sosial keluarga kuat memiliki kemungkinan bermotivasi tinggi 1.4 kali lebih tinggi dari pada mahasiswa

\section{Hasil Analisis Regresi Logistik Ganda}

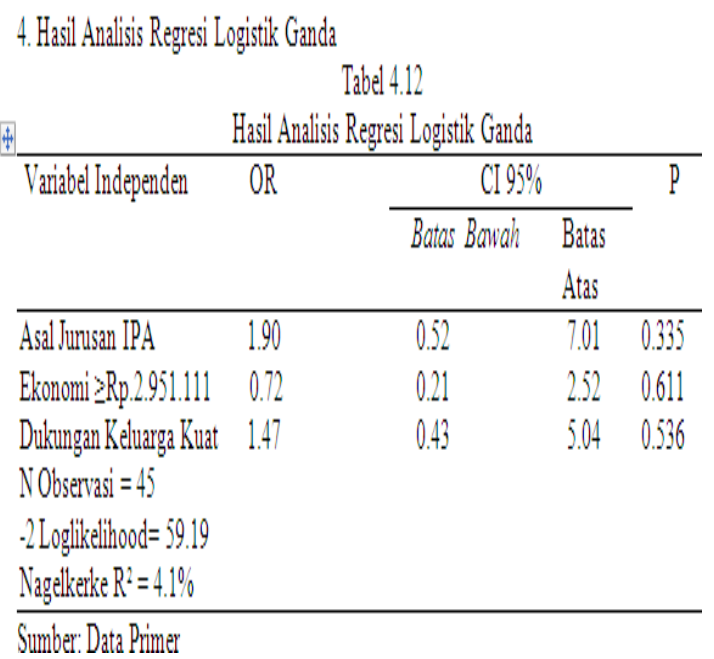

Tabel 4.12 menunjukkan terdapat hubungan positif dengan derajat kekuatan lemah dan secara statistik tidak signifikan. Mahasiswa yang berasal dari jurusan IPA memiliki kemungkinan untuk bermotivasi tinggi 1.9 kali lebih tinggi daripada yang memiliki dukungan sosial keluarga lemah, akan tetapi secara statistik tidak signifikan. mahasiswa yang berasal dari jurusan Non IPA (OR=1.90; $\mathrm{p}=0.335)$.

Ada hubungan yang terbalik, tetapi secara statistik tidak signifikan antara status ekonomi orangtua dengan motivasi belajar. Mahasiswa yang berasal dari status 
ekonomi orangtua $\geq$ Rp.2.951.111 memiliki kemungkinan bermotivasi tinggi 7/10 kali lebih rendah daripada mahasiswa yang berasal dari status ekonomi orangtua $<\mathrm{Rp}$. 2.951.111 (OR=0.72; $\mathrm{p}=0.611)$.

Terdapat hubungan yang positif dengan derajat kekuatan lemah, secara statistik tidak signifikan antara dukungan sosial keluarga dengan motivasi belajar. Mahasiswa dengan dukungan sosial keluarga kuat memiliki kemungkinan untuk bermotivasi tinggi $1.5 \mathrm{X}$ lebih tinggi daripada mahasiswa dengan dukungan sosial keluarga lemah $(\mathrm{OR}=1.47 ; \mathrm{p}$ $=0.536$ ).

\section{Pembahasan}

1. Analisis Hubungan Asal Jurusan dengan Motivasi Belajar

Menurut Subini (2012), motivasi instrinsik dapat memberikan dorongan untuk melakukan sesuatu. Sedangkan menurut Sardiman (2012) motivasi instrinsik adalah motivasi yang tidak perlu dirangsang dari luar, karena dalam diri setiap individu sudah ada dorongan untuk melakukan sesuatu.

Pada kenyataannnya mereka yang berasal dari jurusan yang dianggap kurang relevan atau Non IPA dapat memiliki motivasi belajar lebih tinggi. Menurut Djamarah (2012), ada beberapa cara untuk menumbuhkan motivasi, melalui peningkatan kesadaran kepada mahasiswa agar merasakan pentingnya tugas dan menerimanya sebagai tantangan sehingga mampu untuk bekerja keras dan berusaha dengan segenap tenaga untuk mencapai prestasi. Walaupun karakteristik awal peserta didik perlu diperhatikan, namun untuk motivasi belajar perlu adanya upayaupaya internal untuk menumbuhkannya. Kondisi seperti ini dapat dilakukan oleh dosen pengajar dan dosen wali dengan memberikan wawasan serta wacana masa depan mengenai studi yang sedang ditempuh oleh mahasiswa serta prospek ke depan setelah mereka lulus nanti.

Dengan demikian kalau ada seseorang yang ingin melakukan sesuatu pasti ada alasan atau dorongan (motivasi) yang timbul dalam diri seseorang. Motivasi bisa mendorong manusia mencapai keberhasilan dan survive dalam kehidupan. Oleh karena itu motivasi bagi seorang mahasiswa sangatlah diperlukan untuk memacu keinginan dalam belajar dengan kata lain motivasi belajar harus selalu ditumbuhkan dari dalam diri seorang mahasiswa.

2. Analisis Hubungan Status Ekonomi Orangtua dengan Motivasi Belajar

Mahasiswa yang memiliki pendapatan orangtua diatas rata-rata $(\geq \mathrm{Rp} .2 .951 .111)$ memiliki kemampuan bermotivasi tinggi 8/10 kali lebih rendah daripada mahasiswa dengan pendapatan orangtua di bawah ratarata $(<\mathrm{Rp} .2 .951 .111)$. Dengan status ekonomi orangtua yang menunjang dianggap dapat memenuhi semua fasilitas yang mendukung proses pendidikan yang dibutuhkan oleh putra-putrinya.

Menurut Uno (2010), faktor dari luar diri mahasiswa yang dapat mempengaruhi motivasi belajar adalah apa yang dilakukan orangtua berupa pemberian penghargaan atau fasilitas penunjang pendidikan, pemberian hadiah. Fasilitas penunjang pendidikan yang memadai mampu untuk meningkatkan motivasi belajar. Menurut Djamarah (2012), keluarga miskin kurang mendapatkan kesempatan dalam menempuh pendidikan. Namun pada kenyataannya, tidak sedikit dari mahasiswa yang berasal dari keluarga mampu tidak dapat memanfaatkan fasilitas dan kesempatan yang diberikan oleh orangtua.

Pendapat di atas menunjukkan bahwa motivasi tidak hanya sekedar dapat ditumbuhkan melalui dukungan fasilitas atau materi oleh orangtua, akan tetapi yang 
terpenting adalah keinginan mendalam dari anak untuk melakukan sesuatu. Menurut Sardiman (2012), bahwa motivasi instrinsiklah yang paling dominan menentukan motivasi belajar mahasiswa. Orangtua yang mampu dari segi finansial belum tentu memiliki anak yang bermotivasi tinggi dalam menempuh studi. Hal ini menunjukkan selain faktor ekonomi yang merupakan faktor eksternal, ada faktor internal yang menunjang motivasi belajar mahasiswa.

\section{Analisis Hubungan Dukungan Sosial Keluarga dengan Motivasi Belajar}

Di lihat dari usia responden dapat diklasifikasikan ke dalam remaja akhir sehingga dapat dikategorikan bukan anakanak lagi. Hal tersebut yang menyebabkan mereka dianggap dapat mengatur dirinya sendiri, apalagi mendapat kepercayaan dari orangtua untuk menjalani study lanjut dengan jarak yang berjauhan dengan rumah. Seusia mereka dianggap sudah memiliki keterampilan hidup dalam mengatur kegiatannya sehari-hari. Menurut Erik Ericson (1968), bahwa remaja akhir menginginkan untuk mencapai perilaku sosial yang dapat dipertanggungjawabkan secara sosial serta belajar bergaul dengan kelompoknya. Disinilah mereka banyak menerapkan apa yang menurut mereka benar dilingkungan sosialnya, sehingga kadangkala perhatian atau dukungan yang diberikan keluarga kadang diabaikan.

Dukungan sosial keluarga berupa dukungan informasi, dukungan penilaian, dukungan instrumen dan dukungan psikologis, dimana semua itu adalah motivasi ekstrinsik yang dapat menjadi penunjang dalam menyelesaikan study. Berdasarkan hasil penelitian Adicondro \& Purnamasari, 2011 dukungan keluarga yang berupa dukungan emosi akan memberikan dampak pada anak merasa percaya diri dan tetap mampu merencanakan dan mengontrol kegiatan belajarnya, saat anak diberikan penghargaan akan mendorong anak untuk dapat mengatur dan memonitor kegiatan belajarnya dan menyeleksi lingkungan yang kondusif untuk proses belajarnya. Dukungan informasi yang diberikan keluarga akan membantu mereka mendapatkan informasi yang baik maupun nasehat dari keluarga tentang permasalahan pribadi yang dihadapi, sehingga tetap mampu mengontrol aktifitas belajarnya. Dukungan instrumen dapat terlihat dari upaya orangtua untuk memenuhi fasilitas dan sarana belajar yang baik untuk anak, sehingga anak akan memiliki motivasi untuk mengatur aktifitas belajarnya serta memanfaatkan lingkungan yang kondusif untuk belajar.

Akan tetapi motivasi ekstrinsik dapat juga dikatakan sebagai bentuk motivasi yang didalamnya aktifitas belajar dimulai dan diteruskan berdasarkan dorongan dari luar yang tidak secara mutlak berkaitan dengan aktifitas belajar. Perlu ditegaskan bukan berarti bahwa motivasi ekstrinsik ini tidak baik (Sardiman, 2012). Jadi motivasi belajar pada prinsipnya yang menjadi ukuran penting untuk menumbuhkannya adalah keinginan atau dorongan yang kuat dari dalam mahasiswa sendiri untuk melakukan aktifitas belajar.

Mahasiswa yang merupakan kategori remaja membutuhkan pengakuan akan kemampuannya, yang menurut Maslow kebutuhan ini disebut kebutuhan penghargaan. Remaja membutuhkan penghargaan dan pengakuan bahwa mereka mampu untuk melakukan sesuatu secara mandiri dan menyelesaikan tugas-tugas dengan baik serta dapat mempertanggungjawabkan semua sikap dan perbuatannya. Kebutuhan-kebutuhan semacam ini kadangkala membuat remaja menomerduakan apa yang disampaikan dan diberikan keluarga. 
4.Analisis Hubungan Asal Jurusan, Status Ekonomi Orangtua, Dukungan Sosial Keluarga dengan Motivasi Belajar

Berdasarkan hasil penelitian dari ketiga variabel yang diteliti faktor dominan yang dapat mempengaruhi motivasi belajar adalah asal jurusan, yaitu mahasiswa yang berasal dari jurusan IPA memiliki kemungkinan bermotivasi lebih tinggi sebanyak 1.9 kali daripada mahasiswa yang berasal dari jurusan Non IPA. Jika di lihat dari analisis statistik hubungan itu tidak signifikan.

Motivasi belajar dapat juga dikatakan serangkaian usaha untuk menyediakan kondisi-kondisi tertentu, sehingga seseorang mau dan inin melakukan sesuatu, dan bila ia tidak suka, maka akan berusaha untuk meniadakan dan mengelakkan perasaan tidak suka itu. Dalam kegiatan proses belajar mengajar, motivasi dapat dikatakan sebagai keseluruhan daya penggerak di dalam diri mahasiswa yang menimbulkan kegiatan belajar, yang menjamin dari kelangsungan dari kegiatan belajar dan yang memberikan arah pada kegiatan belajar, sehingga tujuan yang dikehendaki tercapai (Sardiman, 2012).

Motivasi merupakan dorongan diri sendiri, biasanya karena adanya kesadaran akan pentingnya sesuatu. Minat yang besar terhadap sesuatu merupakan modal besar dalam menumbuhkan motivasi (Djaali, 2011). Oleh karena itu faktor latar belakang mahasiswa, asal jurusan, status ekonomi orangtua, dukungan sosial keluarga hanyalah sebagian kecil penunjang motivasi belajar. Semuanya akan kembali kepada kekuatan dan seberapa besar upaya yang dilakukan untuk melaksanakan aktifitas belajar.

Mahasiswa yang berasal dari jurusan IPA, diharapkan memiliki motivasi belajar yang lebih tinggi karena diasumsikan bahwasanya jurusan IPA memiliki memiliki relevasi keilmuan yang sangat erat dengan keperawatan. Mereka yang berasal dari jurusan IPA lebih mudah adaptasi dengan mata kuliah yang diikuti, sehingga lebih termotivasi untuk sukses. Fakta berbicara bahwa siswa yang memilih jurusan IPA adalah siswa yang tekun dalam belajar, sebaliknya jurusan non IPA menjadi pilihan bagi mereka yang tidak tertampung di jurusan IPA (Wulansari, 2010).

Hasil penelitian menunjukkan bahwa mahasiswa semester IV yang berasal dari jurusan IPA hanya memiliki kemungkinan bermotivasi tinggi 1.9 kali dari mahasiswa yang berasal dari jurusan non IPA. Menurut Djaali (2011), motivasi belajar adalah merupakan faktor psikis yang bersifat non intelektual. Peranannya yang khas adalah dalam hal penumbuhan gairah, merasa senang dan semangat untuk belajar. Jadi faktor intelektualitas tidak menjadi penentu tingginya motivasi belajar, walaupun mereka yang berasal dari jurusan IPA ditengarai lebih memiliki intelektual yang tinggi.

Dari hasil penelitian menunjukkan ada hubungan yang terbalik, tetapi secara statistik tidak signifikan. Keadaan status ekonomi orangtua merupakan faktor penentu motivasi belajar mahasiswa. Mahasiswa yang berasal dari latar belakang keluarga mampu, akan mendapatkan peluang yang lebih besar untuk mendapatkan kesempatan dan fasilitas penunjang belajar. Hal ini akan mendorong mereka untuk memiliki gaya hidup yang baik, penuh semangat belajar, berdisiplin dan peduli terhadap masalah pendidikan (Septiningrum, 2011).

Jika melihat hasil penelitian di atas, sesungguhnya tidak menjamin mereka yang berasal dari keluarga mampu akan memiliki motivasi belajar yang tinggi atau sebaliknya mereka yang berasal dari ekonomi rendah akan memiliki motivasi 
yang rendah pula. Orangtua cenderung memenuhi semua fasilitas yang menunjang proses pendidikan, namun apa yang telah diberikan orangtua belum tentu akan dimanfaatkan dan dipersepsikan dengan baik oleh putra putri mereka. Semua tergantung kepada bagaimana mereka mempersepsikan lingkungan belajar mereka. Persepsi adalah proses kognitif di mana individu mengorganisasi, mengenal dan menginterpretasikan yang diperolehnya dari stimulus lingkungan (Purwati, 2011).

Lingkungan yang baik akan membawa mereka pada kondisi yang baik juga, begitu juga sebaliknya. Menurut hukum perkembangan, bahwasanya lingkungan pendidikan akan mempengaruhi mahasiswa dalam belajar, sehingga perlu adanya upaya-upaya seperti menciptakan lingkungan belajar yang kondusif, sering memotivasi mereka untuk belajar serta mengarahkan pada perkembangan yang optimal.

Berdasarkan uraian tersebut, mahasiswa yang berasal dari pendapatan $<$ Rp.2.951.111 bisa memiliki motivasi belajar yang tinggi. Hal tersebut dapat timbul karena adanya keinginan untuk sukses, semangat, ingin menyenangkan orangtua, serta cita-cita masa depan yang sudah mulai mereka pikirkan. Menurut Sardiman (2011), kadang-kadang mereka rela bekerja keras dan belajar giat demi orang yang mereka cintai, misalnya orangtua dan keluarga.

Menurut Jean Jacquea Rousseau, usia 20 tahunan adalah memasuki masa pematangan diri, dalam tahap ini perkembangan fungsi kehendak dan kemauan mulai dominan. Mereka cenderung memilih keinginan yang akan direalisasikan dalam tindakannya. Realisasi setiap keinginan ini menggunakan fungsi penalaran, sehingga orang dalam masa ini mulai mampu melakukan self direction dan self control.

\section{SIMPULAN DAN SARAN \\ Kesimpulan}

Terdapat hubungan dengan kekuatan sedang tetapi secara statistik tidak signifikan antara asal jurusan dengan motivasi belajar. Mahasiswa yang berasal dari jurusan IPA memiliki kemungkinan bermotivasi 1.9 kali lebih tinggi daripada mahasiswa yang berasal dari jurusan Non IPA (OR=1.90, $\mathrm{p}=0.335)$.

Terdapat hubungan yang lemah dan secara statistik tidak signifikan antara pendapatan dengan motivasi belajar $(\mathrm{OR}=0.72, \mathrm{p}=0.611)$. Terdapat hubungan yang positif tetapi lemah dan secara statistik tidak signifikan antara dukungan sosial keluarga dengan motivasi belajar $(\mathrm{OR}=1.47, \mathrm{p}=0.536)$.

\section{SARAN}

1. Bagi Tempat Penelitian

a. Dalam seleksi penerimaan mahasiswa baru, hendaknya benar-benar memilih calon mahasiswa memiliki minat yang tinggi untuk masuk ke suatu program studi.

b. Meningkatkan dan mengoptimalkan peran tenaga pembimbing akademik.

2. Bagi Mahasiswa

Mahasiswa adalah seseorang yang di anggap memiliki self regulated yang baik dalam menghadapi permasalahan yang sedang dihadapi.

3. Peneliti Selanjutnya

Penelitian lebih lanjut dengan variabel yang sama, disarankan menggunakan ukuran sampel yang lebih besar.

Daftar Pustaka

Agustiani, H. 2006. Psikologi perkembangan. Bandung, Refika Aditama. 
Azwar, S. 2011. Tes prestasi fungsi dan pengembangan pengukuran prestasi belajar. Yogjakarta, Pustaka Pelajar.

2011. Sikap Manusia Teori dan Pengukurannya. Yogjakarta, Pustaka Pelajar.

Dahlan, S. 2012. Analisis multivariate regresi logistik. Jakarta, PT. Epidemiologi Indonesia.

Darmawan, W. 2010. Potret kehidupan sosial ekonomi di Kabupaten Indramayu. Jurnal Penelitian Pendidikan. 11 (1): 88-95.

Djaali, 2011. Psikologi pendidikan. Jakarta, Bumi Aksara.

Djamarah, SB. 2011. Psikologi belajar. Jakarta, Bumi Aksara.

Friedman, HS, Schustack, MW. 2006. Kepribadian. Jakarta, Erlangga.

Friedman, MM, Bowden, VR. 2010. Keperawatan keluarga: riset, teori dan praktek. Jakarta, EGC.

Hamalik, O. 2011. Dasar-Dasar Pengembangan Kurikulum. Bandung, PT. Remaja Rosdakarya.

Hamdu, G. 2011. Pengaruh motivasi belajar siswa terhadap prestasi belajar IPA di Sekolah Dasar. Jurnal Penelitian Pendidikan. 12(1): 81-86.

Henny, KA. 2010. Aplikasi praktis asuhan keperawatan keluarga. Jakarta, Sagung Seto.

Kara, 2012. Pengaruh sosial ekonomi orangtua dan motivasi belajar terhadap prestasi belajar siswa. Jurnal Edukasi Nusantara. 1(2): 157-166
Karmawan, 2012. Peranan keluarga dalam meningkatkan motivasi belajar siswa. Jurnal Ilmiah Ilmu Sosial dan Ilmu Politik Untan. 1(0001):19.

Kusuma, BH. \& Bangun, N. 2011. Analisis pemahaman mahasiswa akuntansi terhadap konsep asset, kewajiban, dan ekuitas. Bisnis dan Akuntansi. 13(3): 183-194.

Nilawati, L. \& Bimo, D. Pengaruh motivasi pada kinerja belajar. Jurnal Menejemen Bisnis. 3(3): 287-303.

Notoatmodjo. 2002. Metodologi Penelitian Kesehatan. Yogyakarta: Rineka Cipta.

Nursalam. 2008. Konsep dan Penerapan Metodologi Penelitian Ilmu Keperawatan. Jakarta: Salemba Medika.

Priambodo, A. 2005. Peran keluarga dalam meningkatkan motivasi siswa SLTP untuk mengikuti program pendidikan jasmani dan kesehatan di sekolah. Jurnal Pendidikan Dasar. 6(2): 61-118

Purwadi, A. 2010. Hubungan antara status ekonomi orangtua dan motivasi belajar dengan prestasi belajar IPS kelas IX SMP Negeri 4 Ponjong Gunungkidul Tahun pelajaran 2009/2010. Tesis tidak dipublikasikan, UNS, Solo.

Purwati, A. 2011. Pengaruh status sosial ekonomi orang tua, persepsi atas lingkungan \& prestasi belajar terhadap perilaku konsumsi siswa.Jurnal Ekonomi Bisnis. 1: 1116. 
Premono, A. 2010. Kompetensi keahlian Sekolah Menengah Kejuruan: antara kebijakan dan realita. Jurnal Pendidikan Penabur. 15: 50-61.

Rusmin, AR. 2006. Korelasi antara pendapatan orangtua dengan prestasi belajar mahasiswa. Forum Kependidikan. 26(1): 57-61.

Sardiman, AM. 2012. Interaksi dan motivasi belajar mengajar. Jakarta, Raja Grafindo Persada.

Setiadi, 2008. Konsep \& proses keperawatan keluarga. Yogyakarta, Graha Ilmu.

Soetjiningsih, 2012. Tumbuh kembang anak. Jakarta, EGC.

Subekti, I, Hariyanto, Wiyono, J. 2005. Asuhan keperawatan keluarga konsep \& proses. Malang. Laboratorium Keperawatan Komunitas Prodi Keperawatan.

Subini, 2012. Psikologi pembelajaran. Yogyakarta, Mentari Pustaka.

Sugiyono, 2012. Metode penelitian kuantitatif kualitatif dan risert \& Development. Bandung, Alfabeta.

Uno, H. 2011. Teori motivasi \& pengukurannya. Jakarta, Bumi Aksara.

Murti, B. 2010. Desain dan ukuran sampel untuk penelitian kuantitatif dan kualitatif di bidang kesehatan. Yogyakarta, Gadjah Mada University Press.

Wahyudin, U. 2012. Pola pendampingan keluarga dalam akselerasi program pemberantasan buta aksara tingkat dasar di Desa Mekarmanik Kecamatan Cimenyan Kabupaten
Bandung. Jurnal Penelitian Pendidikan. 13: 53-60.

Wulansari, FC. 2010. Hubungan asal jurusan dengan prestasi belajar mahasiswa tingkat II di Akademi Kebidanan Estu Utomo Boyolali. E-journal Akbid-Purworejo. 1(01): 12-39.

Zakaria, R. 2011. Konteks keluarga dan hubungannya dengan penglibatan ibu bapak dalam pendidikan anakanak di sekolah menengah. Jurnal Pendidikan Malaysia. 36(1): 35-44. 